\title{
Del amor y otros demonios and the Aesthetic Trajectory of García Márquez
}

\author{
Jay Corwin $^{1}$
}

García Márquez's final full length novel, Del amor y otros demonios (1994), presents various difficulties to the reader. The novel's layers of symbolism are readily identifiable with references in the novel to Roman Catholic hagiographies in juxtaposition to qualities and characteristics of the Orishas of the Yoruba Tradition. The period of the novel corresponds temporally with the formation of the syncretic religion known as Santería. The author's use of period techniques such as conceptismo emphasizes the baroque era on a structural level. Furthermore, conceptismo plays a major role in the evolution of themes in the novel, which on final analysis shows distinct parallels with one of the earliest hagiographies of the Roman Catholic corpus. At the same moment, the strings of metaphors and doubling of motifs may also point to extraliterary texts. Those points stated, the novel's African influences may be traced back to one of the author's first stories, "Nabo el negro que hizo esperar a los ángeles" (1951), not merely as a reiteration of themes but as a means of analyzing the earlier piece with a more complete view of the author's aesthetic trajectory. This leads to a clearer understanding of the place of AfroCaribbean religion in García Márquez's works as well as the ultimate refinement of his technical abilities as a novelist. [Article copies available for a fee from The Transformative Studies Institute. E-mail address: journal@transformativestudies.org Website: http://www.transformativestudies.org (02019 by The Transformative Studies Institute. All rights reserved.]

KEYWORDS: Orisha, Hagiography, Oshun, Yemayá, Yoruba, St Dominic, St Agnes of Rome, Santería, Catholicism, Conceptismo, Nabo, Syncretism, Voodoo, Symbolism, Extraliterary References.

\footnotetext{
${ }^{1}$ Jay Corwin, Ph.D., is Senior Lecturer in Spanish. He is the author of La transposición de fuentes indigenas en "Cien años de soledad" (Romance Monographs number 52, 1997), and Gabriel García Márquez (London: Palgrave 2016). He has published analytic essays delving into the indigenous, African and Classical mythological and religious structures in particular writings including those of García Márquez and Jorge Luis Borges, as well as on the psychological framework of Juan Rulfo's Pedro Páramo. Address correspondence to: Jay Corwin; e-mail: jay.corwin@uct.ac.za.
} 